AN ECONOMIC FEASIBILITY ANALYSIS OF INCLUSIONARY ZONING IN TORONTO, ONTARIO

\author{
by \\ Ryo Kikuchi \\ B.A. (Honours), University of Toronto, 2015 \\ A Major Research Paper \\ presented to Ryerson University \\ in partial fulfillment of the requirements for the degree of \\ Master of Planning \\ in \\ Urban Development \\ Toronto, Ontario, Canada, 2017
}

(C) Ryo Kikuchi 2017 
I hereby declare that I am the sole author of this MRP. This is a true copy of the MRP, including any required final revisions.

I authorize Ryerson University to lend this MRP to other institutions or individuals for the purpose of scholarly research.

I further authorize Ryerson University to reproduce this MRP by photocopying or by other means, in total or in part, at the request of other institutions or individuals for the purpose of scholarly research.

I understand that my MRP may be made electronically available to the public. 


\title{
AN ECONOMIC FEASIBILITY ANALYSIS OF INCLUSIONARY ZONING IN TORONTO, ONTARIO
}

\author{
(C) Ryo Kikuchi, 2017 \\ Master of Planning \\ in \\ Urban Development \\ Ryerson University
}

\begin{abstract}
The Government of Ontario has recently introduced legislation which would allow municipalities to implement inclusionary zoning, a policy tool which would require developers to include affordable housing units in new residential developments. This study examines the potential impacts that implementing an inclusionary zoning program would have on the decision making process of developers operating in the Toronto housing market. The author found that without sufficient incentives inclusionary zoning policies impact the financial returns new developments are able to generate. This paper concludes that in order for inclusionary zoning to be successfully implemented without causing financial hardship on developers, incentives such as density bonuses should be offered.
\end{abstract}

Keywords: Inclusionary Zoning, Affordable Housing, Density Bonus 
I would like to extend my appreciation to a number of people that have helped me write this paper.

I would like to thank my supervisor Dr. David Amborski and second reader Dr. Jaclene Begley, who provided me with guidance and support. Their thoughtful feedback and suggestions were very helpful in writing this paper.

I would also like to thank all of the individuals who have provided assistance over the past several months. The completion of this paper would not have been possible without their generous support. 
List of Tables

List of Figures

$\begin{array}{ll}\text { Introduction } & 1\end{array}$

What is Inclusionary Zoning $\quad 4$

Features of IZ programs $\quad 4$

Legislative Framework $\quad 8$

$\begin{array}{lr}\text { U.S. applications } & 9\end{array}$

IZ impacts on the feasibility of new development 14

$\begin{array}{ll}\text { Mandatory vs. voluntary programs } & 18\end{array}$

$\begin{array}{ll}\text { Incentives } & 20\end{array}$

$\begin{array}{ll}\text { Scope of Research Study } & 21\end{array}$

$\begin{array}{ll}\text { Data } & 21\end{array}$

$\begin{array}{ll}\text { Assumptions } & 24\end{array}$

$\begin{array}{ll}\text { Methods } & 26\end{array}$

$\begin{array}{ll}\text { Results and Analysis } & 30\end{array}$

$\begin{array}{ll}\text { Conclusion } & 38\end{array}$

$\begin{array}{ll}\text { References } & 41\end{array}$ 


\section{List of Tables}

Table 1: Purpose-built rental pro forma line items 24

Table 2: Condominium ownership pro forma line items 24

Table 3: Development prototype information 27

Table 4: Summary of different scenarios analyzed 28

Table 5: Rental development pro forma $\quad 30$

Table 6: Rental development pro forma with 10\% set-aside 30

Table 7: Purpose-built rental development pro forma analysis results 30

Table 8: Condominium development pro forma 32

Table 9: Condominium development pro forma with 10\% set-aside 33

Table 10: Condominium development pro forma analysis results 34

Table 11: Condominium development pro forma with $20 \%$ set-aside analysis results 34

Table 12: Condominium development pro forma with density bonus analysis results 34

\section{List of Figures}

Figure 1: Financial gap created from affordable housing provision 


\section{Introduction}

In addition to providing shelter, housing is also a commodity, and is one of the many assets in financial markets where large amounts of capital are invested. As such, addressing the issue of affordability for residents simply seeking housing as shelter becomes much more complex. Residents in municipalities across Ontario such as the City of Toronto are facing increasing housing prices and are unable to secure housing that is affordable (Clayton \& Schwartz, 2015). Average asking prices of new ground-related housing units have doubled since 2005, and average re-sale prices of single-detached homes rose $79 \%$ over the same period (Clayton, 2015). However these increases greatly outpaced general inflation, as the Consumer Price Index rose just 19\% over the same period (Clayton, 2015). In 2015 there were 171,360 seniors, single adults and families on wait lists for rent-geared-to-income housing (ONPHA, 2016). In Ontario, this issue becomes exacerbated considering the recent decreased funding from the upper levels of government for social housing programs (Clayton \& Schwartz, 2015).

Many advocates, including City of Toronto planners, are urging the Government of Ontario to allow municipalities to implement Inclusionary Zoning to combat this housing unaffordability issue. Inclusionary zoning (IZ) is a land use regulation that would either encourage or require (depending on whether it is voluntary or mandatory) developers to include affordable housing units in new residential developments (Hickey, Sturtevant, \& Thaden, 2014).

IZ programs have been introduced in many U.S. municipalities as they are thought to provide several benefits:

- IZ programs create affordable housing options with no financial costs to the local government as they leverage the private sector to create affordable dwelling units. 
- IZ programs avoid creating concentrations of poverty by integrating affordable housing units evenly throughout a community (Clayton \& Schwartz, 2015).

IZ programs have produced approximately 150,000 affordable units, although this figure may not be reliable as it does not account for the units produced and funding raised through in-lieu payments (Urban Land Institute, 2016). Because of the lack of municipal funds involved costs of providing IZ units would mainly be borne by the developers, but also the land owners, buyers of market units, and the community at large (Gladki \& Pomeroy, 2007).

The Government of Ontario has recently introduced legislation which would allow municipalities to implement IZ policies. Therefore this paper will seek to highlight the potential impacts that implementing an IZ program would have on the decision making process of developers operating in the Toronto housing market. This study will create pro formas for development prototypes using current City of Toronto housing market information to highlight the feasibility impacts an IZ program would create. The pro forma analyses will use cost assumptions based on provisions in Bill 204 which highlights how IZ policies will apply in Toronto. For example, based on Bill 204 IZ policies would not allow municipalities to accept payments of cash-in-lieu of the provision of affordable units, and thus for our study we assumed affordable units had to be provided on-site.

The report begins with a literature review on the features of different existing IZ programs, impacts IZ would have on the feasibility of new developments, the difference in mandatory and voluntary programs, and different incentives that have been used thus far. It then examines the potential impacts IZ would have on the feasibility of residential developments in Toronto through a pro forma study. 
Specifically, the paper will seek to answer the following research question:

- What factors would influence the amount of affordable housing units an IZ program can create?

The study will seek to answer the research question by analyzing the cost IZ obligations create on developers. The study will also quantify the value of different incentives which can be offered as part of an IZ obligation. 


\section{What is Inclusionary Zoning}

Inclusionary zoning (IZ) requires new residential developments (both rental and ownership) to provide affordable units through below-market rents or prices. As such, successful creation of affordable units depends on a strong housing market. In many U.S. jurisdictions incentives such as density bonuses are provided to developers to compensate for the loss in providing units at below-market prices (Drdla, 1999).

$\mathrm{IZ}$ is seen as a very appealing policy tool as it requires little to no funds from the local government (Knaap, Bento, \& Lowe, 2008), given the history of precarious funding from the upper levels of government for social housing (Mah, 2009). However, ongoing oversight and management are required on the part of municipalities in order to maintain and preserve affordability for the targeted households (Hickey et al., 2014). Regardless, IZ leverages the private sector to provide affordable housing. Because of this, critics of IZ argue that inclusionary policies decrease housing production and thus increase housing prices (Mah, 2009).

\section{Features of IZ programs}

IZ programs are implemented in more than 500 U.S. jurisdictions, but they all differ from one another in their design and implementation (Urban Land Institute, 2016). Thus understanding how IZ programs have been structured and implemented is a reasonable starting place for answering our research question. Immediately following this section, examples of U.S. application will be examined. The following are some of the major components of IZ programs implemented thus far: 
Mandatory vs. voluntary: As will be discussed later in this paper, mandatory policies require all new residential developments to provide affordable units while voluntary programs offer incentives to developers who participate.

Developments subject to IZ: As highlighted by Richard Drdla Associates (2010) IZ programs can be applied to two types of developments:

1) All developments under existing as-of-right zoning provisions.

2) All developments seeking additional development benefits, such as greater development density.

Developments subject to IZ vary by type and size of development; however most programs require new developments of 10 units or more to provide affordable units (Gladki \& Pomeroy, 2007). Almost all are applied to both rental and ownership housing projects (Mah, 2009). Some jurisdictions may exempt those based on the number of units in a project, or type (some may exempt certain housing types while others may require all housing types of affordable unit provision) (Urban Land Institute, 2016). For example, all new residential developments are subject to IZ in California, while smaller residential developments are exempt in Washington, D.C. (Schuetz, Meltzer, \& Been, 2008).

The set-aside amount: The set-aside amount is the portion of units in a development that must be affordable (Mah, 2009). This varies by jurisdiction, ranging from 5-30\% (Knaap et al., 2008). These can vary within jurisdictions as well: some Boston suburban jurisdictions require 10-15\% to be affordable units, while others require $25 \%$, while some even require $50 \%$ (Schuetz et al., 2008). Sometimes affordable portions can be determined on a sliding scale, which is when developers include a higher portion of affordable units in order to gain higher density bonuses 
(Schuetz et al., 2008). Deciding on a set-aside amount for policy makers is crucial as this will largely impact the returns for a developer and will determine the financial gap the incentive will need to fill.

Income eligibility and duration of affordability: Depending on the jurisdiction affordable units must be affordable to households that earn between 60 to $120 \%$ of the area median income (AMI) (Urban Land Institute, 2016). The length of time which units must be kept affordable vary from 10 to 99 years (Knaap et al., 2008), and some even require units to be kept affordable in perpetuity (Mah, 2009). Typically, affordability duration requirements differ between rental developments and ownership housing. Rental housing is mostly based on agreements which are project specific which determine affordable rent levels for terms of 10 to 35 years, and ownership housing can involve mechanisms such as controls on re-sales on title and restrictions on price increases on re-sale (Gladki \& Pomeroy, 2007). These come in the form of housing agreements or covenants registered on title (Mah, 2009). Re-sale prices are limited to prices less than the market value, which are determined by established formulas (Drdla, 1999). These agreements can also require that municipalities receive a portion of the capital in windfalls in resale prices (Mah, 2009). However, a balance must be struck, in that the owner must be given a reasonable equity stake to encourage purchase, maintain the property and allow them to move up in the market if they desire to do so (Drdla, 1999). In Ontario, housing and rental prices affordable to specific income percentiles are provided in the Provincial Policy Statement. Ontario municipalities currently do not have effective legal tools to ensure affordability after resale (Richard Drdla Associates, 2010).

Opt-outs or alternative contribution options: In some jurisdictions, developers have the option of making payments in-lieu of providing affordable units into a local affordable housing fund, or 
provide the affordable units off-site (Urban Land Institute, 2016). Other buyout options that have been used in some U.S. jurisdictions include the donation of land and transferable development credits (Schuetz et al., 2008). For example, in Washington, D.C., some jurisdictions permit buy-out options if it has been demonstrated that providing affordable units on-site would cause financial hardship (Schuetz et al., 2008). Opt-out options are available for example as affordable units may be desired in a different but more suitable location (Richard Drdla Associates, 2010). Instead of providing affordable units directly on-site, some programs permit developers to provide affordable units in alternative ways, for example, payment of feesin-lieu (Drdla, 1999). Alternative options are included in programs so that if financial hardship is caused on the developer, affordable units can still be created in different manners. Alternative contribution options are also available if the development is in an inaccessible location with a lack of transit service (Porter, 2004). However some programs require affordable units to be provided on-site with no alternative options in order to avoid concentrating low-income families (NPH, 2007).

Incentives: Incentives are provided to developers to offset the loss in revenue from providing affordable units. Incentives that have been provided to date include density bonuses, fee waivers/deferrals, property tax abatements, and fast track processing (Gladki \& Pomeroy, 2007). For example, the IZ program in Brookline, MA offers developers either density bonuses, reduced parking requirements or $\$ 5,000$ in cash as an incentive (Tombari, 2005). Incentives are also provided to avoid legal issues, largely based on the "taking" of property (Mah, 2009). In some cases incentives can also result in a greater profit for developers (Gladki \& Pomeroy, 2007). 


\section{Legislative Framework}

On May 18, 2016 the Ministry of Municipal Affairs and Housing presented Bill 204

"Promoting Affordable Housing Act, 2016". Bill 204 proposes amendments to the Development Charges Act and Planning Act to allow for implementation of IZ policies in Ontario municipalities. Some important provisions include:

- Requiring municipalities to contain policies in their Official Plans which authorize IZ

- Allowing municipalities to pass by-laws which give effect to IZ policies

- Not allowing municipalities to accept cash-in-lieu of the provision of affordable units

- The prohibition of appeals to the Ontario Municipal Board (OMB) with respect to Official Plan and zoning by-law appeals regarding IZ

An IZ program implemented in the City of Toronto would most likely be mandatory as a voluntary program would closely resemble Section 37 of the Planning Act. 


\section{$\underline{\text { U.S. applications }}$}

\section{$\underline{\text { Mandatory vs. voluntary }}$}

Around one-third of programs in Boston are mandatory, but two-thirds of new programs adopted since 2000 have been mandatory (Schuetz et al., 2008). All of the most effective IZ programs in California are mandatory (NPH, 2007). The MPDU program in Montgomery County is mandatory as well (Brown, 2001). In New York City IZ is voluntary, and only mandatory in up-zoned lots (Clayton \& Schwartz, 2015). In the San Francisco Bay Area 48 municipalities have an IZ program, with most being mandatory (Schuetz et al., 2008).

\section{$\underline{\text { Developments subject to IZ }}$}

26 programs in Boston, or about one-third of all programs, utilize minimum size to identify developments subject to IZ, with the average size being eight units (Schuetz et al., 2008). The structure type is what subjects developments to IZ in 18 programs, ranging from multi-family, townhouse, accessory apartment and duplex (Schuetz et al., 2008). For some programs in California, such as those in Atascadero and Carlsbad, IZ policies apply to all new residential developments (CCRH, 2007). Montgomery County's program applies to all new single and multi-family developments of 50 dwelling units and more (Brown, 2001). Similarly, under New York's new Mandatory Inclusionary Housing program all new residential developments in an area zoned for Mandatory Inclusionary Housing will require affordable units (NYC Planning, 2016). Almost all new developments are subject to $I Z$ in most San Francisco programs as the minimum sizes are generally small (Schuetz et al., 2008).

$\underline{\text { Set-aside amount }}$ 
Around $39 \%$ of programs in Boston require up to $10 \%$ of units to be affordable units, $18 \%$ require $11-15 \%$, and $15 \%$ require $16 \%$ or more (Schuetz et al., 2008). For voluntary programs, the developers choose their set-aside percentage, and receive cost-offsets on a sliding scale (Schuetz et al., 2008). In California's most effective programs, set-aside percentages range from $12.5 \%$ to $35 \%$ (NPH, 2007). Set-aside percentages can vary depending on the development type as well: in Davis, California, homeownership and smaller rental developments set-aside $25 \%$ for affordable housing, and rental projects 20 units or more set-aside 35\% (NPH, 2007). The MPDU ordinance requires developments with at least 50 dwellings to set aside $12.5 \%$ to $15 \%$ as affordable units (Brown, 2001). In New York, City Council has the option of applying one or both of the following set-aside requirements to each Mandatory Inclusionary Housing area: 25\% of residential floor area set-aside for affordable units targeted for residents with incomes averaging $60 \%$ of AMI, or $30 \%$ of residential floor area set-aside for affordable units targeted for residents with incomes averaging $80 \%$ of AMI (NYC Planning, 2016). In San Francisco, almost half of the programs require up to $10 \%$ of units to be set-aside as affordable, while another onethird require between $11 \%-15 \%$ (Schuetz et al., 2008). They can also vary within a program as well, as higher requirements are set on larger projects, and a lower requirement can be used if the developer targets the affordable units to the lowest income groups (Schuetz et al., 2008).

Income eligibility and duration of affordability

Around half of IZ programs in Boston target affordable units for low and moderate income households (Schuetz et al., 2008). 17 programs specify units should be affordable to only lowincome households, and one program targets affordable units to "very low" income households (Schuetz et al., 2008). 26 programs do not reference which income levels they target and just simply require units be affordable (Schuetz et al., 2008). In California's top-producing programs 
affordability targets range from very low to moderate incomes, where half specify the breakdown of the income mix while others leave the income targeting to decision making bodies such as a planning commission or City Council (NPH, 2007). Montgomery County's program targets households earning 65\% or less of the AMI (Brown, 2001). If the developer is unable to sell or rent an affordable unit to an eligible participant within 90 days the developer can sell or rent the unit to anyone (Brown, 2001). In New York IZ targets affordable units for households earning either $80 \%$ or $60 \%$ of the AMI depending on the option exercised (Clayton \& Schwartz, 2015). In San Francisco affordable units are most commonly set aside for either very-low, low, and moderate-income households (Schuetz et al., 2008). Many programs target rental units for lowincome households, and ownership units for moderate-income households (Schuetz et al., 2008).

$34 \%$ of programs in Boston require units to be affordable for 80 or 99 years, or permanently affordable (Schuetz et al., 2008). 6\% require a 20 year length of affordability (Schuetz et al., 2008). About half of the programs do not specify a set affordability duration or use language such as "as long as allowable under state law" (Schuetz, Meltzer, \& Been, 2011). California's top-producing programs require a minimum affordability period of 30 years, and re-sale controls, deed restrictions and developer contracts are used to maintain affordability (NPH, 2007). Montgomery County's IZ program requires rental units be affordable for 20 years, and regulates ownership units for 10 years (Brown, 2001). Affordable dwelling unit owners may sell the unit before the 10 year time frame but there are limits on the listing price they can ask for (Brown, 2001). However if the unit is sold after the 10 year period the owner may sell the unit with no limit on the asking price (Brown, 2001). Owners may keep $\$ 10,000$ or half of the total profit, and the remainder goes into Montgomery County's Housing Initiative Fund (Brown, 2001). New York's Mandatory Inclusionary Housing program requires units to be permanently 
affordable (NYC Planning, 2016). The highest proportion of programs in San Francisco require units to be affordable for either 30 years, 40 to 49 years, 50 to 59 years, or in perpetuity (Schuetz et al., 2008).

\section{Opt-outs}

Only 38\% of programs in Boston feature opt-out or buyout options (Schuetz et al., 2011). In California's top-producing programs alternatives to on-site construction include payment of inlieu fees, land dedication, off-site construction and credit transfers (NPH, 2007). In Montgomery County developers can build more affordable units off-site, provide land off-site, or provide payment to the county's housing trust fund (Brown, 2001). In New York, developers may provide affordable units off-site but are required to provide an additional $5 \%$ of affordable units (NYC Planning, 2016). In-lieu fees, off-site construction, land donation and transferable development credits are some opt-out options in San Francisco (Schuetz et al., 2008).

\section{$\underline{\text { Incentives }}$}

Density bonuses are the most common incentive in Boston's IZ programs (Schuetz et al., 2008). Other programs relax zoning requirements such as frontage or lot sizes (Schuetz et al., 2008). In California, the most common incentives include financial subsidies, followed by density bonuses, permit related incentives and technical assistance (NPH, 2007). In Montgomery County a sliding scale system determines the density bonus amount, but developers are allowed a density bonus of up to 22\% (Brown, 2001). In New York's voluntary program, density bonuses and tax breaks are the most common incentives (Clayton \& Schwartz, 2015). In the new mandatory program, no specific cost offsets have been identified. Density bonuses, fast- 
tracking of permitting, fee waivers, and provision of other subsidies are some incentives used in San Francisco programs (Schuetz et al., 2008). 


\section{IZ impacts on the feasibility of new development}

Of all of the actors in the development process, the developers arguably take on the most amount of risk, and thus expect to reap a target profit margin (Black, 2012). Therefore, if a pro forma for a residential development failed to generate a target financial return, the project would not be undertaken.

Two types of impacts can be identified:

1) The impact of a new IZ program on a pro forma where the land has already been purchased.

2) The impact of an IZ program on a pro forma where the land has not been purchased.

Under the first scenario, a developer has already purchased the site at a market price, and thus the developer may have to accept a lower net cash flow on their investment. This is because the developer is already locked in on the site purchased, and thus does not have the option of building their development in another location. If the developer is not willing to accept a lower net cash flow they may increase the prices/rents on their market rate dwelling units to make up for the financial gap if no cost offsets are provided. In this scenario a possible impact on the housing market could be an increase in average market prices or rents.

Under the second scenario however, the developer has the option of not proceeding with the development in that specific location, if they are not willing to accept a lower net cash flow. If the incentive sufficiently offsets the cost of providing affordable units however, the developer may still proceed with the development. In this scenario a possible impact on the housing market could be a shortage of housing supply in that community. 
The biggest concern of IZ from builders and developers is that IZ policies impact the financial returns of new developments.

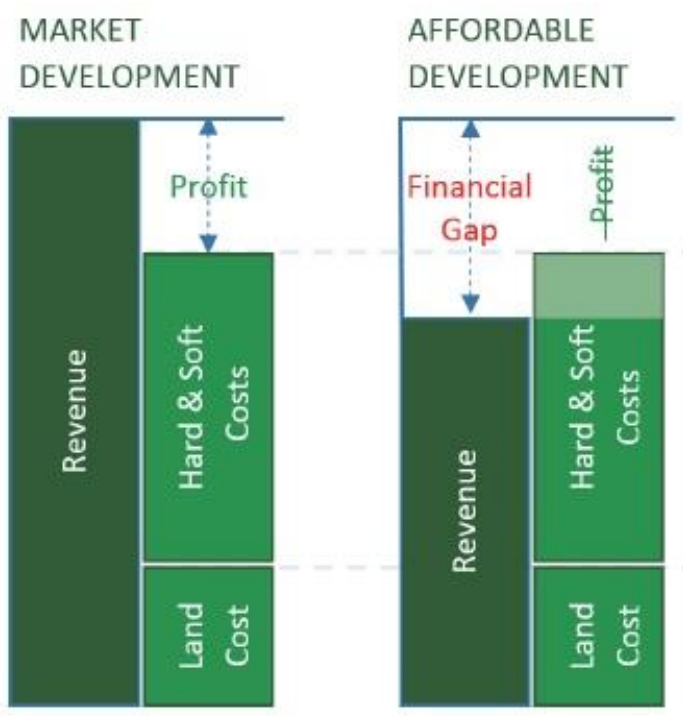

Figure 1: Financial gap created from affordable housing provision. Source: City of Mississauga (2016)

IZ impacts new housing developments as they lower the net operating income, which is the rent revenues minus the operating costs (Urban Land Institute, 2016). As the Urban Land Institute (2016) highlights, developers dealing with IZ have three options:

1) Not build their housing development in that location, and proceed with the development in a nearby jurisdiction with no IZ policies.

2) Persuade the owner of the site to sell for a below-market price; however most landowners will not agree to this option.

3) Proceed with the development and with the lower net cash flow; however most developers will not proceed with this option.

Under the following two scenarios however, new developments can be built without having to face the previously mentioned options (Urban Land Institute, 2016): 
1) The revenue generated from rents or sales from market-rate units are high enough to compensate the loss in rent or sales revenue from providing affordable units.

2) The jurisdiction provides incentives to mitigate the costs of providing affordable units on the feasibility of the development.

In addition, the set-aside amount impacts the feasibility of a development as well, as the average per unit revenue declines as set-aside percentages increase (Urban Land Institute, 2016).

The effectiveness of IZ also depends on the sub-market. Because IZ depends on the development of market-rate housing and the rents and sales prices they can demand, in jurisdictions of weaker markets, fewer affordable units are able to be developed as developments in these jurisdictions are unable to support construction costs and land prices (Urban Land Institute, 2016). Therefore an IZ program with an incentive of density bonuses may be able to create affordable units in neighbourhoods with high-rents, but not in neighbourhoods with lower rents (Madar \& Willis, 2015). Rents must be at a certain level to provide a healthy financial return on all hard and soft costs.

Private sector developers are very reluctant in providing rental housing developments rather than condominium developments, let alone affordable rental housing developments, as without subsidies from the government, they are not financially feasible (Black, 2012). The rental housing stock in Toronto has not grown much since the 1990s although housing starts have generally increased during the same period (Mah, 2009). Multi-unit rental possesses greater risk and thus lenders pass the risk onto developers by requiring them to purchase mortgage insurance from the Canada Mortgage and Housing Corporation (CMHC) to protect themselves from loan default and delayed debt service payments (Black, 2012). Most if not all developers focus on 
condominium ownership developments as relatively high rents are needed to make a rental development feasible, where there is little market demand for these high rent thresholds (City of Mississauga, 2016). Rental housing developments are also less profitable compared to condominium developments, even though land and construction costs are very similar (Black, 2012). However, the increase in demand for rental housing along with the shortage in purposebuilt rental apartment supply has resulted in condominium apartment units being increasingly used for rental purposes (City of Mississauga, 2016).

For many U.S. jurisdictions with IZ programs, the incentives provided failed to compensate for the loss in revenue, and thus developers elected not to participate and develop at all (Urban Land Institute, 2016). Some programs offer alternatives to providing affordable units on-site, such as providing land to the municipality, payments in-lieu of construction and providing units on another site owned by the same developer (Gladki \& Pomeroy, 2007). However the alternatives are structured to encourage affordable units to be provided on-site and thus attempting to provide units off-site comes with a cost premium (Gladki \& Pomeroy, 2007). In addition, concerns about marketability with affordable units in the development have been voiced by developers as well (Drdla, 1999). 


\section{Mandatory vs. voluntary programs}

If an IZ program is mandatory in a municipality, developers can only escape the cost of affordable units by not proceeding with the development at all. Affordable housing units must be included for a developer to receive development approval in mandatory programs (Drdla, 1999). For voluntary programs, developers are encouraged to participate but do not necessarily have to, in exchange for incentives (Drdla, 1999). In rare cases developers will proceed with the development if they are willing to accept a lower financial return. If IZ in the municipality is voluntary, a developer will have the option of proceeding with a development if the government incentive (such as a density bonus) compensates for the loss in revenue from providing affordable units and makes them indifferent than if IZ did not apply.

From a developer's perspective, voluntary programs are more attractive as they can be just as efficient as mandatory programs if incentives are sufficient (Drdla, 1999). Mandatory programs would be added bureaucracy and fees that developers must face (Mah, 2009). Voluntary programs are also more attractive for municipalities as they are less likely to face legal challenges and opposition from developers (Drdla, 1999). In Chicago a hybrid approach is used, where affordability requirements are triggered only when City owned land is purchased, zoning amendment involving increased density or land use change is requested, or when the City provides financial assistance (Mah, 2009).

A mandatory program would be more restrictive and may have a greater likelihood of decreasing the housing supply than a voluntary program, with all else being equal (Schuetz et al., 2011). In New York City’s voluntary “Inclusionary Housing Program” developers elect to participate if they are able to make up for the lost revenue through building additional market 
rate units through the received incentive such as a density bonus (Madar \& Willis, 2015). This voluntary program is also less restrictive than a mandatory program as affordable units do not necessarily have to be provided directly on-site: they could be provided in another site within the same community district or within a half mile in an adjacent district, meaning if providing onsite would cause financial hardship, developers can provide units elsewhere (Madar \& Willis, 2015). A mandatory program thus carries the risk of limiting development, if affordability requirements are too strict or developers can't adjust to the new economic landscape (Madar \& Willis, 2015). However, evidence from U.S. experiences suggests that voluntary programs are less productive at producing affordable units than mandatory ones (Drdla, 1999).

As mentioned previously a mandatory program carries the risk of limiting new developments in a community. Critics argue that IZ is a form of what economists call a price control, economic policies which are used to tackle inflation (Tombari, 2005). IZ would act as an additional cost on housing construction, and thus this cost would be passed on to housing consumers, through a decreased housing supply and increased housing prices (Knaap et al., 2008). For example, the IZ programs in Boston were found to have had various negative impacts on the local housing market: over a period from $1987-2004$, IZ programs have resulted in a $10 \%$ decline in housing starts, and a $1 \%$ increase in single-family housing prices (Urban Land Institute, 2016). 


\section{Incentives}

To compensate for the lost revenue of providing affordable housing units, municipalities generally provide incentives for the developer in one form or another. Otherwise, if the income generated from market-rate housing units is not sufficient enough to compensate for the loss in revenue from providing affordable units at below-market rents, the development becomes financially unattractive, and the development may not be built at all (Madar \& Willis, 2015). Therefore, the role incentives play becomes very important, as it can ultimately be the deciding factor between a development becoming feasible or not becoming feasible.

Incentives must generally fill the financial gap created from the lost revenue in creating units priced at below-market rates. Incentives include those which increase development capacitysuch as density bonuses-and accommodations or easements during the development review process, such as the waiving of development charges for affordable units (Hickey et al., 2014). The most extensively used incentives are density bonuses, although expedited approval and reductions in development standards resulting in cost savings have also been utilized (Drdla, 1999).

Developers seek the highest possible financial return for the resources invested (City of Mississauga, 2016). Therefore, critics have argued that IZ can hurt the feasibility of many potential housing developments, leading to many significant impacts, such as a shortage in the supply of housing (Clayton \& Schwartz, 2015). A decrease in the supply of market-rate housing units alone would increase the prices of housing for instance. Incentives provided to developers as part of an IZ program must bridge the financial gap of the revenue difference for the same development but one under IZ. 


\section{Scope of research study}

The purpose of this study is to further our understanding as planners the impacts a policy tool such as IZ has on the feasibility of new housing developments, and the challenges associated with attempting to leverage the private sector to provide affordable housing.

Pro formas for a development prototype using property information shown in Table 3 will be constructed, for both ownership and rental.

\section{Data}

The pro formas used for the rental development prototypes for a build and hold scenario use the line items as seen in Table 1 to obtain the total cash flow. Total cash flow is important as it must generate a sought after financial return for the developer after covering all costs, such as debt servicing and development charges. The following are cost assumptions used as inputs in the pro forma analysis. Similarly, pro formas used for the condominium ownership development prototypes use the line items as seen in Table 2.

Potential Gross Revenue: Potential Gross Revenue (PGR) represents the total possible revenue the property can generate through rents. Including affordable units per IZ therefore lowers PGR, but PGR is also affected by market rents generated from leasable commercial space if the building is mixed-use.

Vacancy: The vacancy line item reflects current market vacancy figures and is subtracted from PGR as a percentage of the PGR figure. At the time this study was conducted the vacancy rate for the downtown Toronto submarket was $1.30 \%$, and was obtained from the housing market information portal from CMHC. 
Effective Gross Income: Effective Gross Income (EGI) is calculated from subtracting the vacancy figure from PGR. EGI reflects the actual rent revenue that the property generates before operating expenses and debt servicing costs.

Operating Expenses: After EGI is calculated line items such as operating expenses are usually subtracted from EGI. For this exercise operating expenses were assumed to be $40 \%$ of PGR.

Development charge: Development charges are fees issued to the developer to help pay for new infrastructure required to service the new development. Development charges are assessed at the time the building permit is issued, and are thus included in year 1.

Contingency: This line item allows developers to budget for possible cost overruns in the case of unforeseen events occurring, and is usually $5 \%$ of total project costs.

Net Operating Income: Net Operating Income (NOI) is calculated by subtracting expenses from the EGI. Debt servicing is paid out from NOI, and is an important figure as it is used to estimate the value of the property.

Debt service payment: Debt service payments are mortgage payments for the permanent financing loan. Interest rates were assumed to be the prime rate plus an additional $2 \%$. Prime rates were $2.70 \%$ according to the Bank of Canada website at the time this study was conducted.

Property cash flow: The property level cash flow is derived from subtracting debt service payments from the NOI.

Sale Price: Sale price is calculated by dividing the NOI from the year after sale by the cap rate. The NOI from the year after sale is used as this reflects the NOI that the next owner will receive. 
Equity in and Net Cash from sale: Net cash from sale is calculated by subtracting the remaining mortgage balance at the end of the year of sale from the sale price of the property.

Total return: Total return is calculated by adding the equity in and net cash from sale and the property cash flow of the year of sale.

Total cash flow: Total cash flow equals the property cash flow, but in the year of sale total cash flow equals the total return figure. Total cash flow is used to calculate return metrics such as NPV and IRR. 
Table 1: Purpose-built rental pro forma line items

\begin{tabular}{l} 
Set-up \\
\hline Potential Gross Revenue \\
Vacancy \\
\hline Effective Gross Income \\
\hline Operating Expenses \\
Development Charge \\
\hline Contingency \\
\hline Developer Commission \\
\hline Net Operating Income \\
\hline Debt Service Payment \\
\hline Property Cash Flow \\
\hline Sale Price \\
Equity in and Net Cash from Sale \\
\hline Total Return \\
\hline Total Cash Flow
\end{tabular}

Table 2: Condominium ownership pro forma line items

\begin{tabular}{l} 
Sales \\
\hline Uses \\
\hline Site purchase \\
hard costs \\
soft costs \\
interest carry \\
Development charges \\
Contingency \\
\hline Developer commission \\
\hline Total uses \\
\hline Net after uses \\
\hline Sources \\
\hline Debt \\
Debt Repayment \\
Equity \\
\hline Equity Repayment \\
\hline Profit \\
\hline Total Sources
\end{tabular}

\section{Assumptions}

Assumptions are the inputs used in the pro forma to calculate expenses and revenue.

- Land price (per sq.ft.): \$160. This was obtained from the MCAP GTA \& Southwestern Ontario Residential Land Value Market Report. 
- Construction costs: Construction costs were obtained from the Altus Group's "2016 Canadian Cost Guide”. Buildings 13-39 storeys would cost $\$ 260$ per sq.ft. and thus this amount will be used. This amount is multiplied by the total gross floor area of the building to get total construction costs (or hard costs), which is $\$ 69,047,420$ (\$260 $\mathrm{x}$ 265,567 sq.ft.).

- Soft costs: Soft costs were assumed to be $30 \%$ of hard costs, and include expenses for marketing, design, legal, marketing, etc.

- Hurdle rate/discount rate: Hurdle rates, or discount rates, are minimum financial returns that developers will require in all of their property investments. Discount rates are used to discount back a series of future cash flows into today's dollars. A hurdle rate of $8 \%$ was chosen for this exercise, which is the return that would be received on a Government of Canada bond (around $2.14 \%$ as of March $29^{\text {th }}$ ) plus inflation (2\% as of February) plus an additional return required for the additional risk involved with investing in real estate. This hurdle rate will also be used as our discount rate for net present value calculations.

- Development timeline: The development timeline, or the construction period for both the rental and ownership prototypes are 2 years.

- Loan to value: The loan to value (LTV) ratio is the mortgage balance divided by the purchase price of the property. For the condominium prototypes the LTV ratio is $75 \%$.

- Capitalization rate: The capitalization rate (cap rate) is the percentage used to determine the market value of a property. The market value of a property is determined by dividing the NOI of the year after the property is sold by the cap rate. Thus, a lower cap rate would mean a higher market value, and a higher cap rate would result in a lower market value. Cap rates are based on the market and not by the developers themselves, as they 
are based on appraisals of recent sales of similar properties (Black, 2012). Cap rates for the fourth quarter of 2016 for both low-rise and high-rise multi-family developments were in the $3.50 \%-4.75 \%$ range, according to Colliers International.

- Construction loan interest rate: Construction loan interest rates approximately equal the permanent financing loan interest rate plus an additional 200 basis points. Therefore an interest rate of $6.7 \%$ was assumed for this exercise.

- Average rent: Average rent prices were obtained from the Rental Market Report published quarterly by the Toronto Real Estate Board.

- Sale price per square foot: According to real estate brokerage RedPin the average sale price per sq.ft. in the downtown Toronto submarket for the sale period of January to April 2016 is $\$ 622$ (RedPin, 2016). The sale price per square foot will be used to determine the revenue from unit sales the condominium prototypes may generate. A cap rate valuation method is used at the end of the hold period to determine a market value for the entire property as opposed to prices for individual units.

\section{Methods}

Real estate developers utilize pro formas as part of their decision making process when determining whether or not to proceed with a new development. Utilizing pro formas in our analyses will help us to understand issues and challenges developers would face when IZ policies are present. Pro formas also help illustrate whether or not a new development is financially feasible. Thus, to analyze the feasibility of developments subject to IZ policies, spreadsheet pro formas for 3 purpose-built rental prototypes and 7 condominium ownership prototypes were created. 
Density bonuses as an incentive will be examined on the impact of development feasibility as they are the most extensively used incentive in the U.S. In addition, waiving development charges for affordable units as an incentive will be examined as well as it creates real cash reductions in development costs and thus are easy to identify in the pro formas.

The base case is a 34 storey mixed use building containing retail and residential units. Prototype information is taken from a zoning amendment application that proposed to redevelop a site in the downtown core of the City of Toronto with a 34 storey mixed use building. Both the purpose-built rental and condominium ownership development prototypes will use the same property information as shown in Table 3. The development will contain 350 residential units. Market-rent units and affordable units are assumed to be identical in size and cost. Development information is summarized below.

Table 3: Development prototype information

\begin{tabular}{|l|l|}
\hline Storeys & 34 \\
\hline Residential units & 350 \\
\hline One-bedroom units & 210 \\
\hline Two-bedroom units & 116 \\
\hline Three-bedroom units & 24 \\
\hline Market rent for one-bedroom units & $\$ 1,776.00$ \\
\hline Market rent for two-bedroom units & $\$ 2,415.00$ \\
\hline Market rent for three-bedroom units & $\$ 3,283.00$ \\
\hline Average sale price of market-rate units & $\$ 444,673$ \\
\hline Residential GFA & 250,218 \\
\hline Commercial GFA & 15,349 \\
\hline Total GFA & 265,567 \\
\hline Commercial Rent per sq.ft. & $\$ 29.20$ \\
\hline Affordable rent & $\$ 1,340$ \\
\hline Affordable ownership price & $\$ 297,000$ \\
\hline
\end{tabular}

The Ministry of Municipal Affairs and Housing publishes affordable rent and ownership

housing prices based on income percentiles to accompany the Provincial Policy Statement. Affordable housing costs based on the $60^{\text {th }}$ income percentile will be used for this analysis. 
Using the base case prototypes, set-aside requirements of $10 \%$ and $20 \%$ will be examined, along with incentives of a $10 \%$ density bonus and waiving development charges on the affordable units.

Several financial ratios will be utilized to examine the different prototypes:

Net Present Value: The Net Present Value (NPV) formula discounts a stream of cash flows back at a discount rate/hurdle rate for a total sum in today's dollars, minus the initial investment outlay. A positive figure would indicate the property is yielding a return higher than the discount rate, and vice versa.

Internal Rate of Return: The Internal Rate of Return (IRR) of an investment plus yearly future cash flows is the discount rate that causes the NPV to be 0 .

Cash on cash return: The cash on cash return shows the return on the investment based on the equity amount invested.

The different scenarios analyzed are summarized below:

Table 4: Summary of different scenarios analyzed

\begin{tabular}{|l|l|}
\hline Purpose-built rental & Condominium \\
\hline Scenario 1: Base case & Scenario 4: Base case \\
\hline Scenario 2: 10\% set-aside requirement & Scenario 5: 10\% set-aside requirement \\
\hline Scenario 3: 20\% set-aside requirement & $\begin{array}{l}\text { Scenario 6: 10\% set-aside requirement with } \\
\text { incentive (development charge waive) }\end{array}$ \\
\hline & Scenario 7: 20\% set-aside requirement \\
\hline & $\begin{array}{l}\text { Scenario 8: 20\% set-aside requirement with } \\
\text { incentive (development charge waive) }\end{array}$ \\
\hline & $\begin{array}{l}\text { Scenario 9: 10\% set-aside requirement with } \\
\text { incentive (density bonus) }\end{array}$ \\
\hline & $\begin{array}{l}\text { Scenario 10: 20\% set-aside requirement with } \\
\text { incentive (density bonus) }\end{array}$ \\
\hline
\end{tabular}

Waiving development charges for affordable units were not analyzed for the rental development prototypes as return calculations were based off of NOI for this analysis rather than 
property cash flow. This was done as for the rental prototypes debt servicing costs were simply too high based off of the hard and soft costs and so even without an IZ requirement the prototypes would generate negative returns after debt servicing. As the prototypes start generating rental revenues beginning in year 2, development charges (which were assumed to be an outlay in year 1) were not included in our financial calculations. Other line items such as developer commission and contingency were not included as well. To provide a better analysis and understanding of the impacts of IZ NOI was therefore used as positive returns were generated before debt service payments. Normally all of these line items would be included in financial calculations and property level cash flow (which includes debt service payments) rather than NOI should be examined. 


\section{$\underline{\text { Results and Analysis }}$}

Table 5: Rental development pro forma

\begin{tabular}{|c|c|c|c|c|c|c|}
\hline Set-up & Year 0 & Year 1 & Year 2 & Year 3 & Year 4 & Year 5 \\
\hline Potential Gross Revenue & & & $\$ 1,180,082.80$ & $\$ 1,195,423.88$ & $\$ 1,210,964.39$ & $\$ 1,226,706.92$ \\
\hline Vacancy & & & $-\$ 15,341.08$ & $-\$ 15,540.51$ & $-\$ 15,742.54$ & $-\$ 15,947.19$ \\
\hline Effective Gross Income & & & $\$ 1,164,741.72$ & $\$ 1,179,883.37$ & $\$ 1,195,221.85$ & $\$ 1,210,759.73$ \\
\hline Operating Expenses & & & $-\$ 349,422.52$ & $-\$ 353,965.01$ & $-\$ 358,566.55$ & $-\$ 363,227.92$ \\
\hline Development Charge & & $-\$ 5,149,694.12$ & & & & \\
\hline Contingency & & $-\$ 5,089,518.51$ & & & & \\
\hline \multicolumn{7}{|l|}{ Developer Commission } \\
\hline Net Operating Income & & & $\$ 815,319.21$ & $\$ 825,918.36$ & $\$ 836,655.29$ & $\$ 847,531.81$ \\
\hline
\end{tabular}

Line items for a pro forma for a purpose-built rental development not subject to IZ would

look something like that shown in Table 5. Investor cash flow is not shown in our analysis here

(which would include the debt servicing costs) as for the purpose-built rental prototypes even

with no affordable housing requirement the property would be generating a negative return based on market rents and construction costs.

Table 6: Rental development pro forma with $10 \%$ set-aside

\begin{tabular}{|c|c|c|c|c|c|c|}
\hline Set-up & Year 0 & Year 1 & Year 2 & Year 3 & Year 4 & Year 5 \\
\hline PGR from market rent units & & & $\$ 659,050.00$ & $\$ 667,617.65$ & $\$ 676,296.68$ & $\$ 685,088.54$ \\
\hline PGR from affordable units & & & $\$ 46,900.00$ & $\$ 47,509.70$ & $\$ 48,127.33$ & $\$ 48,752.98$ \\
\hline Vacancy & & & $-\$ 9,177.35$ & $-\$ 9,296.66$ & $-\$ 9,417.51$ & $-\$ 9,539.94$ \\
\hline Effective Gross Income & & & $\$ 696,772.65$ & $\$ 705,830.69$ & $\$ 715,006.49$ & $\$ 724,301.58$ \\
\hline Operating Expenses & & & $-\$ 209,031.80$ & $-\$ 211,749.21$ & $-\$ 214,501.95$ & $-\$ 217,290.47$ \\
\hline \multicolumn{7}{|l|}{ Development Charge } \\
\hline \multicolumn{7}{|l|}{ Contingency } \\
\hline \multicolumn{7}{|l|}{ Developer Commission } \\
\hline Net Operating Income & & & $\$ 487,740.86$ & $\$ 494,081.49$ & $\$ 500,504.55$ & $\$ 507,011.10$ \\
\hline
\end{tabular}

Table 6 shows the pro forma for the same prototype but with $10 \%$ of its units rented out as affordable units. The NOI is lowered as revenues fall but costs remain the same.

Table 7: Purpose-built rental development pro forma analysis results

\begin{tabular}{|l|l|l|l|}
\hline & $\begin{array}{l}\text { Scenario 1: Purpose-built } \\
\text { rental - base case }\end{array}$ & $\begin{array}{l}\text { Scenario 2: Purpose-built } \\
\text { rental - 10\% set-aside }\end{array}$ & $\begin{array}{l}\text { Scenario 3: Purpose-built } \\
\text { rental - 20\% set-aside }\end{array}$ \\
\hline Affordable units & 0 & 35 & 70 \\
\hline Market rent units & 350 & 315 & 280 \\
\hline Total units & 350 & 350 & 350 \\
\hline NOI & $\$ 815,319.21$ & $\$ 487,740.86$ & $\$ 469,217.83$ \\
\hline $\begin{array}{l}\text { Value @ end of hold } \\
\text { period of 25 years }\end{array}$ & $\$ 29,643,064.16$ & $\$ 17,733,095.63$ & $\$ 17,059,642.42$ \\
\hline
\end{tabular}




\begin{tabular}{|l|l|l|l|}
\hline NPV & $\$ 4,840,126.50$ & $-\$ 876,068.70$ & $-\$ 1,199,292.90$ \\
\hline IRR & $11 \%$ & $7 \%$ & $7 \%$ \\
\hline Cash on cash return & $9 \%$ & $2 \%$ & $2 \%$ \\
\hline
\end{tabular}

As shown in Table 7 above in scenario 1 where no affordable units are provided the property would generate an NOI in its first year of operation $\$ 815,319.21$. The value at the end of a 25 year hold period using a cap rate of $3.75 \%$ would be $\$ 29,643,064.16$. The NPV is $\$ 4,840,126.50$, meaning our prototype would generate a higher return than the discount rate of $8 \%$. The IRR generated would be $11 \%$, which is also a higher rate of return than our hurdle rate. The cash-on-cash return is $9 \%$.

Providing $10 \%$ and $20 \%$ of units as affordable units would decrease the NOI in the first year of operation down to $\$ 487,740.86$ and $\$ 469,217.83$, respectively. Developers will most likely not proceed with the development unless they are willing to accept a lower financial return. However most developers will not accept a financial return lower than their hurdle rate. Hurdle rates for developers are often the return they would receive on a risk-free investment such as a government bond plus some risk premium associated with investing in real estate. The values for developments in scenarios 2 and 3 are lower compared to scenario 1 as the NOI is capitalized into the value of the developments. A negative NPV in both scenarios 2 and 3 means that a $10 \%$ and $20 \%$ IZ set-aside trigger would cause the prototype to generate a return less than our chosen discount rate of $8 \%$. The IRR and the cash on cash returns for both scenarios 2 and 3 are lower as well. 
Table 8: Condominium development pro forma

\begin{tabular}{|c|c|c|c|}
\hline & Year 0 & Year 1 & Year 2 \\
\hline Sales & & $\$ 78,265,988.80$ & $\$ 78,265,988.80$ \\
\hline \multicolumn{4}{|l|}{ Uses } \\
\hline Site purchase & $\$ 4,109,120.00$ & & \\
\hline hard costs & $\$ 34,523,710.00$ & $\$ 34,523,710.00$ & \\
\hline soft costs & $\$ 10,357,113.00$ & $\$ 10,357,113.00$ & \\
\hline interest carry & $\$ 3,117,414.86$ & $\$ 4,802,189.30$ & \\
\hline Development charges & & & $\$ 5,149,694.12$ \\
\hline Contingency & & & $\$ 5,089,518.51$ \\
\hline Developer commission & & & $\$ 31,306,395.52$ \\
\hline Total uses & $\$ 52,107,357.86$ & $\$ 49,683,012.30$ & $\$ 41,545,608.15$ \\
\hline Net after uses & $-\$ 52,107,357.86$ & $\$ 28,582,976.50$ & $\$ 36,720,380.65$ \\
\hline \multicolumn{4}{|l|}{ Sources } \\
\hline Debt & $\$ 28,639,666.36$ & & \\
\hline Debt Repayment & & $\$ 28,582,976.50$ & $\$ 56,689.86$ \\
\hline Equity & $\$ 23,467,691.50$ & & \\
\hline Equity Repayment & & & $\$ 23,467,691.50$ \\
\hline Profit & & & $\$ 13,195,999.29$ \\
\hline Total Sources & $\$ 52,107,357.86$ & $\$ 28,582,976.50$ & $\$ 36,720,380.65$ \\
\hline \multicolumn{4}{|l|}{ Financial ratios } \\
\hline IRR & $16 \%$ & & \\
\hline PV & $\$ 57,947,526.81$ & & \\
\hline NPV & $\$ 5,840,168.95$ & & \\
\hline
\end{tabular}

Table 8 shows the pro forma for the development prototype in a condominium ownership scenario with no IZ policy. The unit mix is the same as that of the base case rental development prototype. The sales revenue was calculated by multiplying the total square footage of residential gross floor area by the sale price per sq.ft. These pro formas reflect a shorter timeline as developers usually sell the development after construction. This base case would generate a healthy return of $16 \%$ and an NPV of $\$ 5,840,168.95$ based on an $8 \%$ discount rate. 
Table 9: Condominium development pro forma with $10 \%$ set-aside

\begin{tabular}{|c|c|c|c|}
\hline Condow/IZ@10\% set-aside & Year 0 & Year 1 & Year 2 \\
\hline Sales & & $\$ 70,484,209.00$ & $\$ 70,484,209.00$ \\
\hline Sales from affordable units & & $\$ 5,197,500.00$ & $\$ 5,197,500.00$ \\
\hline \multicolumn{4}{|l|}{ Uses } \\
\hline Site purchase & $\$ 4,109,120.00$ & & \\
\hline hard costs & $\$ 34,523,710.00$ & $\$ 34,523,710.00$ & \\
\hline soft costs & $\$ 10,357,113.00$ & $\$ 10,357,113.00$ & \\
\hline interest carry & $\$ 3,117,414.86$ & $\$ 4,802,189.30$ & \\
\hline Development charges & & & $\$ 5,149,694.12$ \\
\hline Contingency & & & $\$ 5,089,518.51$ \\
\hline Developer commission & & & $\$ 31,306,395.52$ \\
\hline Total uses & $\$ 52,107,357.86$ & $\$ 49,683,012.30$ & $\$ 41,545,608.15$ \\
\hline Net after uses & $-\$ 52,107,357.86$ & $\$ 25,998,696.70$ & $\$ 34,136,100.85$ \\
\hline \multicolumn{4}{|l|}{ Sources } \\
\hline Debt & $\$ 28,639,666.36$ & & \\
\hline Debt Repayment & & $\$ 25,998,696.70$ & $\$ 2,640,969.66$ \\
\hline Equity & $\$ 23,467,691.50$ & & \\
\hline Equity Repayment & & & $\$ 23,467,691.50$ \\
\hline Profit & & & $\$ 8,027,439.69$ \\
\hline Total Sources & $\$ 52,107,357.86$ & $\$ 25,998,696.70$ & $\$ 34,136,100.85$ \\
\hline \multicolumn{4}{|l|}{ Financial ratios } \\
\hline IRR & $10 \%$ & & \\
\hline PV & $\$ 53,339,071.75$ & & \\
\hline NPV & $\$ 1,231,713.89$ & & \\
\hline
\end{tabular}

The pro forma for the same development but subject to IZ is shown in Table 9. Similar to the pro forma for the rental development prototype sales revenue from the market priced units fall as there are less market priced units generating market sales.

The following summary tables for the condominium developments will highlight the net cash flow in the $2^{\text {nd }}$ year of operation as opposed to the $1^{\text {st }}$ to reflect the impact of the development charge (which is paid out in the $2^{\text {nd }}$ year).

Table 10: Condominium development pro forma analysis results

\begin{tabular}{|l|l|l|l|}
\hline & $\begin{array}{l}\text { Scenario 4: Condominium } \\
- \text { Base case }\end{array}$ & $\begin{array}{l}\text { Scenario 5: Condominium } \\
-10 \% \text { set-aside }\end{array}$ & $\begin{array}{l}\text { Scenario 6: Condominium } \\
-10 \% \text { set-aside with } \\
\text { incentive }\end{array}$ \\
\hline Affordable units & 0 & 35 & 35 \\
\hline Market rent units & 350 & 315 & 315 \\
\hline Total units & 350 & 350 & 350 \\
\hline Net return after uses & $\$ 36,720,380.65$ & $\$ 34,136,100.85$ & $\$ 34,628,165.85$ \\
\hline
\end{tabular}




\begin{tabular}{|l|l|l|l|}
\hline $\begin{array}{l}\text { Value @ end of hold } \\
\text { period }\end{array}$ & - & - & - \\
\hline NPV & $\$ 5,840,168.95$ & $\$ 1,231,713.89$ & $\$ 1,653,580.32$ \\
\hline IRR & $16 \%$ & $10 \%$ & $10 \%$ \\
\hline
\end{tabular}

Similar to the rental development prototypes, in scenario 5 requiring the prototype to provide

affordable units reduces the year over year cash flow, the NPV and the IRR. Under a 10\% set-

aside requirement the returns however do not fall below the $8 \%$ hurdle rate as the NPV remains

positive. Developers faced with this scenario would still be able to proceed with the

development.

Table 11: Condominium development pro forma with $20 \%$ set-aside analysis results

\begin{tabular}{|l|l|l|l|}
\hline & $\begin{array}{l}\text { Scenario 4: Condominium } \\
- \text { Base case }\end{array}$ & $\begin{array}{l}\text { Scenario 7: Condominium } \\
-20 \% \text { set-aside }\end{array}$ & $\begin{array}{l}\text { Scenario 8: Condominium } \\
-20 \% \text { set-aside with } \\
\text { incentive }\end{array}$ \\
\hline Affordable units & 0 & 70 & 70 \\
\hline Market rent units & 350 & 280 & 280 \\
\hline Total units & 350 & 350 & 350 \\
\hline Net return after uses & $\$ 36,720,380.65$ & $\$ 31,551,821.05$ & $\$ 32,535,951.05$ \\
\hline $\begin{array}{l}\text { Value @ end of hold } \\
\text { period }\end{array}$ & - & - & - \\
\hline NPV & $\$ 5,840,168.95$ & $-\$ 3,376,741.17$ & $-\$ 2,533,008.32$ \\
\hline IRR & $16 \%$ & $3 \%$ & $5 \%$ \\
\hline
\end{tabular}

With a higher set-aside requirement in scenario 7 the returns become much lower as reflected

in the lower IRR and NPV figures. In fact, with an $8 \%$ hurdle rate this development now

becomes non-feasible as the NPV becomes negative. Waiving development fees would not

offset this impact as the NPV is still negative as shown in scenario 8.

Table 12: Condominium development pro forma with density bonus analysis results

\begin{tabular}{|l|l|l|l|l|}
\hline & $\begin{array}{l}\text { Scenario 5: } \\
\text { Condominium }-10 \% \\
\text { set-aside }\end{array}$ & $\begin{array}{l}\text { Scenario 9: } \\
\text { Condominium - 10\% } \\
\text { set-aside with density } \\
\text { bonus }\end{array}$ & $\begin{array}{l}\text { Scenario 7: } \\
\text { Condominium }- \\
\text { 20\% set-aside }\end{array}$ & $\begin{array}{l}\text { Scenario 10: } \\
\text { Condominium - 20\% } \\
\text { set-aside with density } \\
\text { bonus }\end{array}$ \\
\hline Affordable rents & 35 & 35 & 70 & 70 \\
\hline Market rent units & 315 & 350 & 280 & 315 \\
\hline Total units & 350 & 385 & 350 & 385 \\
\hline $\begin{array}{l}\text { Net return after } \\
\text { uses }\end{array}$ & $\$ 34,136,100.85$ & $\$ 41,917,880.65$ & $\$ 31,551,821.05$ & $\$ 39,333,600.85$ \\
\hline $\begin{array}{l}\text { Value @ end of } \\
\text { hold period }\end{array}$ & - & & - & \\
\hline NPV & $\$ 1,231,713.89$ & $\$ 15,108,687.47$ & $-\$ 3,376,741.17$ & $\$ 10,500,232.41$ \\
\hline
\end{tabular}




\begin{tabular}{|l|l|l|l|l|}
\hline IRR & $10 \%$ & $28 \%$ & $3 \%$ & $22 \%$ \\
\hline
\end{tabular}

As shown in Table 12 a 10\% density bonus increases returns as there are more allowable market priced units. A condominium development with $20 \%$ set-aside requirements would generate a negative NPV but would generate a positive NPV with the density bonus. As illustrated between scenario 8 and scenario 10, a density bonus acts as a far more superior incentive as illustrated in the return metrics.

This analysis highlights several key findings:

- As construction costs for affordable units would be the same as those for market priced units with all else being equal a development subject to IZ would generate less revenue without sufficient incentives.

- Requiring developments to provide affordable units without providing adequate incentives to make up for the loss in revenue would also hurt the value of the development with all else being equal. Because the NOI in the year following the end of the hold period is divided by the residual cap rate to figure out the value for the development, a lower NOI results in a lower value.

- The IZ condominium scenarios illustrate that set-aside requirements of higher than $20 \%$ may be feasible in the downtown Toronto submarket if an incentive of a $10 \%$ density bonus is provided.

- One possible reason for the development prototypes being financially feasible even when subject to IZ could be due to the high rents and sales prices the units are able to charge. These prototypes were based on market assumptions of the downtown core of the City of Toronto, where rents and sales prices are among the highest in the GTA. These results 
can drastically alter based on the sub-market and what the market rents and sales prices are.

- Rental developments are far less profitable than condominium ownership developments even though costs for land and construction are similar. They are not feasible without sufficient subsidies compared to condominium developments as Black (2012) has highlighted.

- A density bonus would be more beneficial for a developer as an incentive than waiving development charges on affordable units.

- Developers will not likely provide affordable units without support in the form of incentives to bridge the financial gap between providing market rate and affordable units. This finding is reinforced in the City of Mississauga's (2016) report on incentives for affordable housing development.

- The incentive to make developments subject to IZ feasible depends on the financial gap between the revenue generated from market rate and affordable units. This financial gap will depend on the required rates of return of individual developers.

- Returns on the condominium prototype base case vs. the returns on the condominium prototypes with density bonuses suggest that with the sales prices market units are able to charge in the downtown Toronto submarket there is incentive to provide affordable units just to receive the density bonus.

- A risk of reduced supply resulting from developers electing not to proceed with developments in IZ communities can be offset with an incentive that neutralizes the cost of providing affordable units (Gladki \& Pomeroy, 2007). However in our analysis 
waiving development charges associated with the provision of affordable units did not bring the financial return up to par with the same development with no affordable units.

- The production of affordable units through IZ depends on a strong housing market with ample market rate developments and market rents to generate a significant amount of affordable units. 


\section{Conclusion}

As our analysis on rental development prototypes have shown developers of purpose-built rental developments face a major fiscal challenge when faced with having to provide affordable units. For rental developments, lower rent revenues also affect the development's ability to secure financing as the ability to pay mortgages falls with NOI (Gladki \& Pomeroy, 2007). This results in developments requiring larger equity investments and therefore impacting the developer's return on equity (Gladki \& Pomeroy, 2007). This is problematic given the fact that renters make up a larger portion of households in core housing need than owners and the growing income gap between the two (Mah, 2009). For rental housing developments further caution should be used on over restrictive IZ programs as economic feasibility is already slim.

Recommendations for successful implementation of IZ in Toronto are as follows:

- Policies should be tailored to municipalities based on different housing market conditions. In addition, a province wide program may not be appropriate given the different housing markets and the achievable rents each can achieve. Furthermore, a balance between fixed and flexible regulations should be considered which treat all developers fairly but with flexibility to adapt regulations to site-specific conditions (Richard Drdla Associates, 2010). This would allow for determining regulatory concessions based on consideration of the development context (Richard Drdla Associates, 2010).

- An IZ program implemented in Toronto must offer developers sufficient incentives in order to mitigate the negative impacts on developers' pro formas. As highlighted in our pro forma analysis some incentives may be more effective than others in terms of filling 
the financial gap made from providing affordable units. This is especially important for weaker housing sub-markets as lower rents and sales prices are able to be demanded.

- Examining the option of implementing IZ policies only for developments seeking additional development benefits such as density bonuses, as current City of Toronto zoning by-laws are heavily under-zoned as a result of harmonizing 6 zoning by-laws before amalgamation.

- IZ programs implemented should offer a range of opt-out options: for example, in Washington, D.C., some jurisdictions permit buy-out options if it has been demonstrated that providing affordable units on-site would cause financial hardship (Schuetz et al., 2008). This means that even if providing affordable units on-site impacts the feasibility of the development it doesn't create a shortage in affordable housing in the community. Currently however Ontario's draft legislation "Long-Term Affordable Housing Strategy" does not permit cash-in-lieu contributions. Developers would rather provide cash-in-lieu of providing affordable units as they fear that it will be harder to market residential projects which contain affordable units (Mah, 2009). Cash-in-lieu can be directed to an affordable housing fund and used for various housing programs.

The intent of this research paper has been to better our understanding of the challenges developers face when IZ is implemented. This was done by closely examining the decision making process of the private-sector actors when participating in the provision of affordable housing. The evident impacts IZ creates on new developments as highlighted in our pro forma analyses would suggest that a newly implemented program must carefully take these impacts into consideration. In fact, when a municipality adopts any new policy tool it must carefully construct the policies so as to minimize any possible negative externalities. In order to mitigate 
negative impacts on the local housing market, an IZ program must be carefully constructed based on findings from experiences in other jurisdictions. 


\section{$\underline{\text { References }}$}

Altus Group. (2016). Canadian Cost Guide 2016.

Black, J. (2012). The Financing \& Economics of Affordable Housing Development: Incentives and Disincentives to Private-Sector Participation. Toronto: Cities Centre University of Toronto.

Brown, K.D. (2001). Expanding Affordable Housing through Inclusionary Zoning: Lessons from the Washington Metropolitan Area. Washington: Brookings Institution Center on Urban and Metropolitan Policy.

Bank of Canada. (n.d.). Daily Digest. Retrieved from http://www.bankofcanada.ca/rates/dailydigest/.

CMHC. (n.d.). Housing Market Information Portal. Retrieved from https://www03.cmhcschl.gc.ca/hmiportal/en/\#Profile/227001/5/Toronto\%20(Central)

CCRH. (2007). Affordable by Choice: Trends in California Inclusionary Housing Programs.

Colliers International. (2016). Canada Cap Rate Report.

City of Mississauga. (2016). Understanding the Cost of Incentives. NBLC.

City of Toronto. (2017). Development Charges Rates. Retrieved from http://www1.toronto.ca/City\%20Of\%20Toronto/Corporate\%20Finance/Developmental\% 20Charges/Files/pdf/D/DC\%20Rates\%20-\%20Feb\%201\%202017.pdf

Clayton, F. (2015). Why there is a Shortage of Ground Related Housing in the GTA. Toronto: The Centre for Urban Research and Land Development.

Clayton, F.A., \& Schwartz, G. (2015). Is Inclusionary Zoning a Needed Tool for Providing Affordable Housing in the Greater Golden Horseshoe? Toronto: Centre for Urban Research and Land Development.

Drdla, R. (1999). Municipal Regulatory Initiatives: Providing for Affordable Housing. Ottawa: Canada Mortgage and Housing Corporation.

Gladki, J., \& Pomeroy, S. (2007). Implementing Inclusionary Policy to Facilitate Affordable Housing Development in Ontario. Toronto: Ontario Non-Profit Housing Association.

Hickey, R., Sturtevant, L., \& Thaden, E. (2014). Achieving Lasting Affordability through Inclusionary Housing. Cambridge: Lincoln Institute of Land Policy.

Knaap, G.J., Bento, A., \& Lowe, S. (2008). Housing Market Impacts of Inclusionary Zoning. National Center for Smart Growth Research and Education.

Mah, J. (2009). Can Inclusionary Zoning Help Address the Shortage of Affordable Housing in Toronto? Toronto: Canadian Policy Research Networks. 
Madar, J., \& Willis, M. (2015). Creating Affordable Housing out of Thin Air: The Economics of Mandatory Inclusionary Zoning in New York City. New York: NYU Furman Center. Retrieved from http://furmancenter.org/files/NYUFurmanCenter_CreatingAffHousing_March2015.pdf

MCAP. (2016). MCAP GTA \& Southwestern Ontario Residential Land Value Market Report.

NPH. (2007). Affordable by Choice: Trends in California Inclusionary Housing Programs.

NYC Planning. (2016). Mandatory Inclusionary Housing. Retrieved from https://www1.nyc.gov/site/planning/plans/mih/mandatory-inclusionary-housing.page

ONPHA. (2016). 2016 Waiting Lists Survey Report. Retrieved from https://www.onpha.on.ca/onpha/CMDownload.aspx?ContentKey=85812d7f-2d88-4b28bbb2-9a76990de22d\&ContentItemKey=bdeeb1f1-c466-4ffe-a10e-a2b35370e7fe.

Porter, D.R. (2004). Inclusionary Zoning for Affordable Housing. Washington, D.C.: Urban Land Institute.

Province of Ontario. (2014). 2014 Provincial Policy Statement. Retrieved from the Ministry of Municipal Affairs and Housing: http://www.mah.gov.on.ca/AssetFactory.aspx?did=10463

RedPin. (2016). What is the average price per square foot in Toronto? Retrieved from https://blog.theredpin.com/blog/average-price-per-square-foot-toronto-condo/

Rosen, D. (2004). Inclusionary Housing and its Impact on Housing and Land Markets. NHC Affordable Housing Policy Review.

Richard Drdla Associates (2010). A Guide to Developing an Inclusionary Housing Program.

Schuetz, J., Meltzer, R., \& Been, V. (2008). 31 Flavors of Inclusionary Zoning: Comparing Policies from San Francisco, Washington, D.C. and Suburban Boston. New York: NYU Furman Center.

Schuetz, J., Meltzer, R., \& Been, V. (2011). Silver Bullet or Trojan Horse? The Effects of Inclusionary Zoning on Local Housing Markets in the United States. Urban Studies,48(2), 297-329.

Toronto Real Estate Board. (2016). Rental Market Report Fourth Quarter 2016.

Tombari, E.A. (2005). Smart Growth, Smart Choice Series: The Builder's Perspective on Inclusionary Zoning". National Association of Home Builders.

Urban Land Institute. (2016). The Economics of Inclusionary Development. 